\title{
TESTING ENERGY CONSUMPTION IN THE TROLLEYBUS AND THE BUS ON A CHOSEN PUBLIC TRANSPORT LINE IN LUBLIN
}

\author{
Ewa Siemionek ${ }^{1}$, Mieczysław Dziubiński $^{1}$ \\ 1 Mechanical Engineering Faculty, Lublin University of Technology, Nadbystrzycka 36, 20-618 Lublin, Poland, \\ e-mail: e.siemionek@pollub.pl; m.dziubinski@pollub.pl
}

Received: 2015.04.16

Accepted: 2015.05.08

Published: 2015.06.01

\begin{abstract}
One of the most important elements determining the assessment of the quality of trolleybuses and buses in public transport is the operating cost which comprises mainly the cost of power or fuel consumption. The knowledge of economic properties of new vehicles is justified when the decision about their purchase is being made. The information about vehicles which have not been used in the company so far comes mainly from the protocols of homologation tests as well as the opinions of other users. In both cases such knowledge is insufficient against the expected information providing for specific driving conditions in urban traffic. Chosen driving tests applied for the evaluation of energy consumption of trolleybuses and buses operation are presented in the article. Working conditions of the trolleybus were analysed on the basis of the comparative tests of the bus and the trolleybus for a chosen communication line in Lublin. On the basis of the determined characteristics describing working conditions of the vehicles constituting public transport in Lublin, the MPKPL test was drawn up and the analysis of findings was carried out for a chosen communication line.
\end{abstract}

Keywords: energy consumption, public transport, trolleybuses.

\section{INTRODUCTION}

The cost of power consumed by public transport vehicles constitutes a considerable part of balance sheets of communication companies. Economic properties of trolleybuses, including power consumption, are one of the basic factors determining the assessment of the trolleybus quality. Great importance is also attached to the cost of purchase, service, reliability and durability.

There are many representative driving cycles drawn up mainly by automotive organizations and institutions or European circles for environmental protection. The cycles are mostly designed for light vehicles, motor cars, and those designed for goods vehicles include only information about engine worktime at a given load. All the cycles are intended to test emissions of car exhaust fumes and do not reflect the real driving conditions of the car and especially of the trolleybus or the city bus driving cycles on a road without a special bus lane.
Fuel consumption in buses is examined in driving tests with assumed speed courses. A relevant problem is synthesizing the driving test taking into account the criteria of the resemblance of operational use conditions and tests carried out for buses and trolleybuses for a given network of communication lines.

Tests carried out for the Municipal Public Transport Company in Lublin showed that the conditions of trolleybuses use, including the kind of communication line determining the character of their functioning, had a significant effect on power consumption in trolleybuses.

The source of information concerning economic properties is mainly the protocols of homologation tests as power consumption was analysed for trolleybuses not used in public transport companies. It is also possible to gain knowledge about power consumption in a given type of a trolleybus from other users $[1,2,5]$. 


\section{METHODOLOGY AND COURSE OF EXAMINATION}

In the course of the study, road measurements were taken, including geographic coordinates, times of stops and rides, speeds, acceleration of buses and trolleybuses driving on chosen transport routes. A selected number of 10 stops and landform features were aimed at reflecting in an accurate way the movement of the bus and the trolleybus in the conditions of normal work of the carrier for both types of vehicles. In Figures 1 and 2, chosen time characteristics of speed for the tested vehicles have been presented [8].
Measurements were taken for a random number of passengers, changing at each bus stop. They were taken repeatedly on separate driving routes and the findings were averaged. On the basis of road measurements of real city vehicle driving cycles were carried out in the area of Lublin city, a representative driving cycle called MPKPL was developed. The developed representative driving cycle reflects real driving conditions of buses, including such parameters as achieved speeds and speeding up as well as the duration of stops and driving at a constant speed. The speed profile of the representative MPKPL cycle is presented in Figure 3.

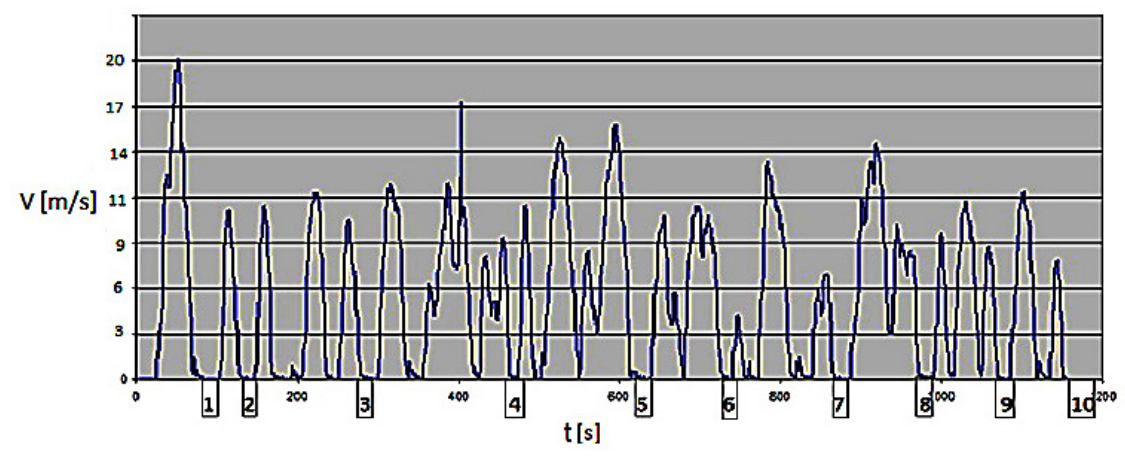

Fig. 1. Graph presenting speed in the function of time for the trolleybus during the ride Mickiewicza stop - Honorowych Krwiodawców roundabout

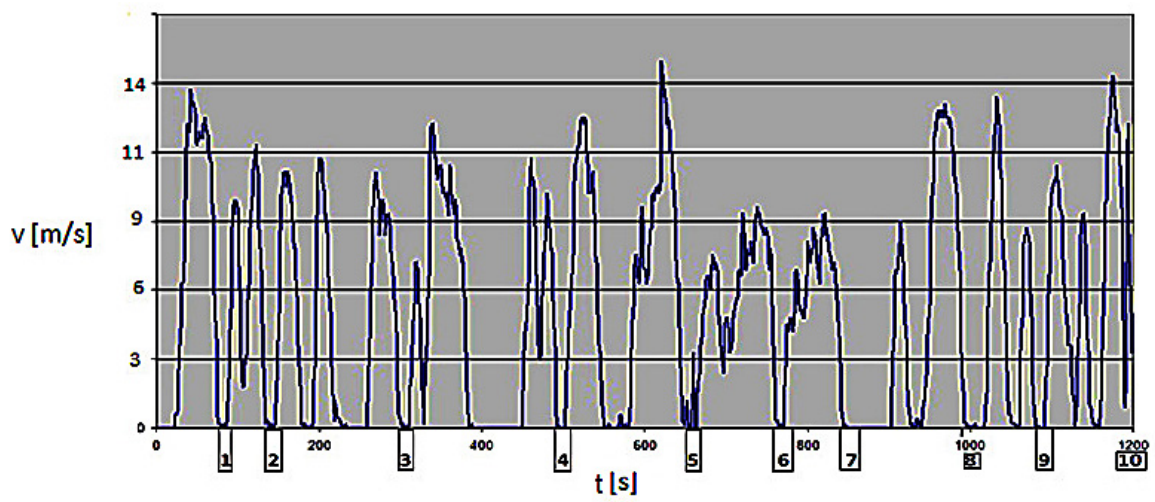

Fig. 2. Graph presenting speed in the function of time for the bus during the ride Honorowych Krwiodawców roundabout stop - Mickiewicza

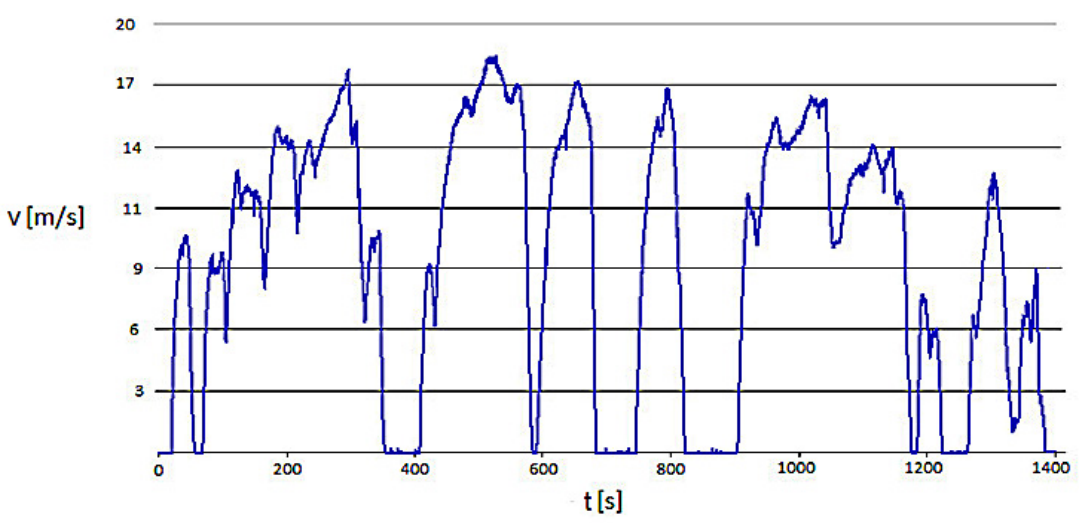

Fig. 3. Velocity profile of the representative MPKPL cycle 
The length of the route is $8000 \mathrm{~m}$, the average speed $15 \mathrm{~m} / \mathrm{s}$, the maximum speed $18 \mathrm{~m} / \mathrm{s}$. The average driving speed includes not only the motion but also breaks related to passengers' getting on and off - from the moment of starting at the first stop to the moment of finishing at the last stop.

\section{ANALYSIS OF ENERGY CONSUMPTION}

Energy balance of the representative driving cycle was prepared on the basis of data for the trolleybus Solaris Trollino 12 and the bus Solaris Urbino 12.

Regarding weekly energy or fuel consumption, driving conditions on weekdays are more significant than those on weekend days. It results from a much bigger number of weekdays and realized transport routes.
Figure 4 shows the dependence of unitary energy consumption on the load of city transport vehicle after the percentage of seats taken on buses and trolleybuses have been analyzed. It can be concluded from this relationship that at the load equal to the number of seats, the consumption is about $50-100 \%$ higher than for a nominal load, however, at the little load, unitary consumption rises disproportionally.

Regarding distances between bus stops, unitary energy consumption is inversely proportional to the distance between stops $L$ which is shown in Figure 5. The influence of little road inclination is practically of no importance for energy consumption, and with proper placing of stops and braking with energy recovery, the consumption could be even reduced.

The efficiency of converting energy in electric and combustion drives depends largely on the

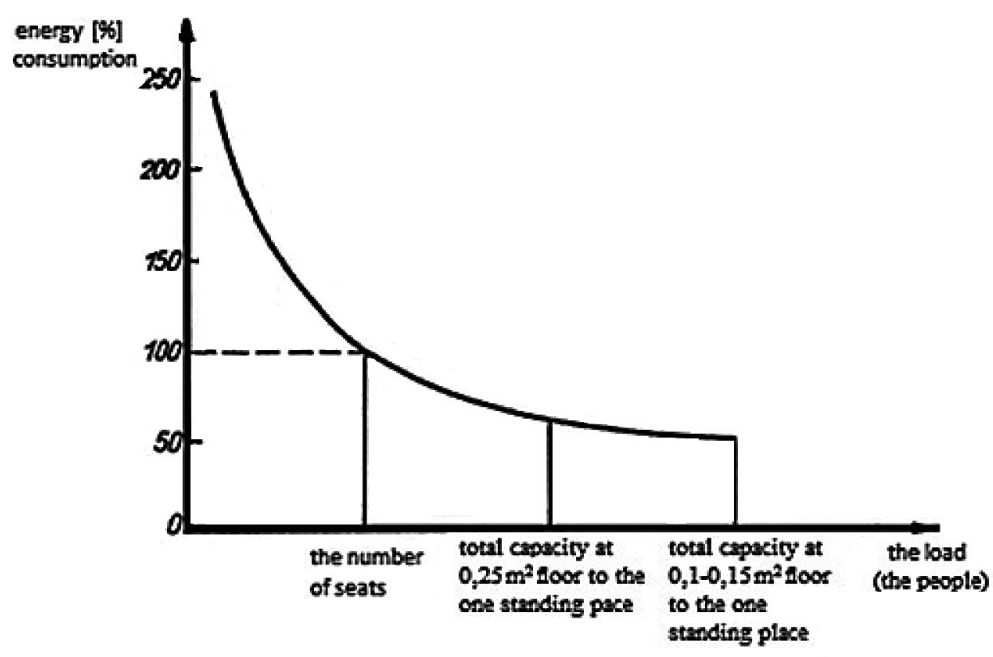

Fig. 4. Dependence of unitary energy consumption on the load of city transport vehicle [4]

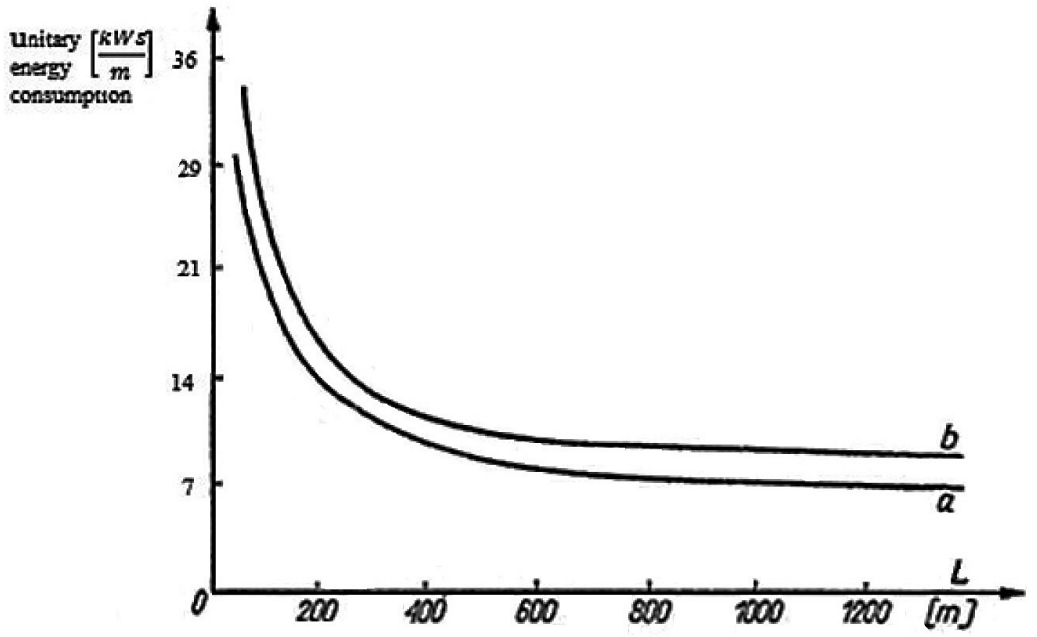

Fig. 5. Unitary energy consumption depending on the distance between stops $L$ [4] 


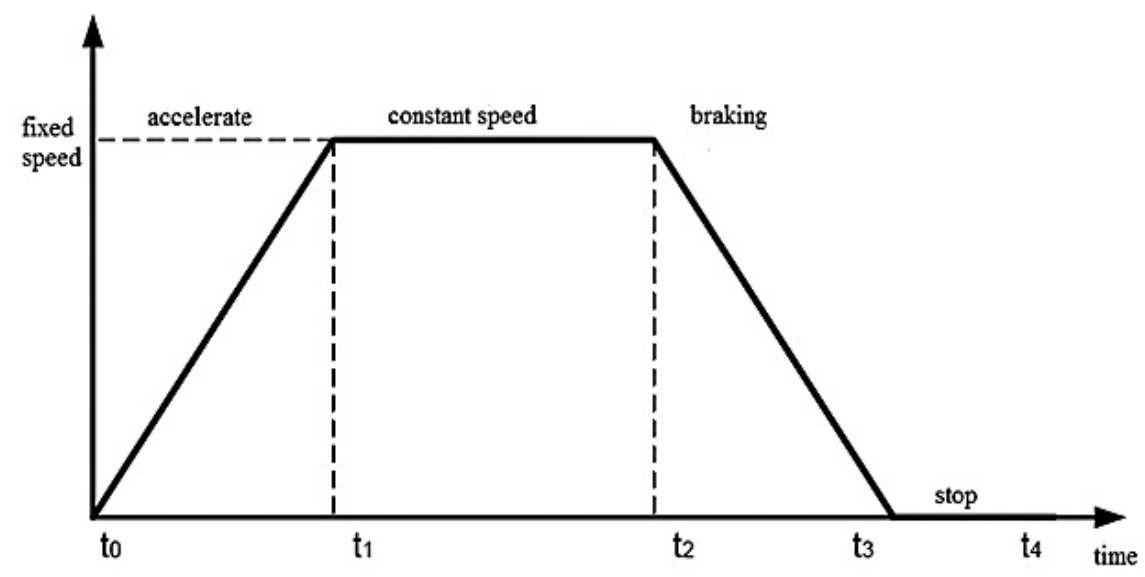

Fig. 6. Elementary car driving cycle [7]

profile of a given driving cycle. Figure 6 shows a basic car driving cycle.

An elementary driving cycle consists of acceleration phases until the set speed is reached, driving at an established speed, braking and a stop. When the vehicle accelerates, energy is used to realize effective work (overcoming resistance to motion and increasing kinetic energy of the vehicle) and making up for the loses in the power transmission system. The power needed to accelerate the vehicle to a set speed is much bigger than the one needed to drive it at a constant speed. However, when braking, the kinetic energy accumulated in the vehicle mass and rotating inertia masses is lost in a form of thermal energy in the vehicle friction brakes. The abrasion of friction surfaces causes the wear of brake lining as well as brake disks and drums, whereas the rubbed dust pollutes the environment. The energetic efficiency of drive systems was analyzed assuming that the trolleybus and the bus are of the same mass and have the same traction parameters, move on the same road and in the same driving cycle (a stop, accelerating, driving at the established speed, braking) $[3,6]$.

\section{CONCLUSIONS}

On the basis of professional literature, it can be stated that one of the basic criteria in evaluating means of city transport is their operating cost, dependent on energy consumption, in the conditions of real-life operational use.

Empirical research of buses and trolleybuses on selected communication lines has been conducted as part of the project 'Multidimensional analysis of means of city transport with regard to their operation and energy consumption'. On the grounds of the results of the conducted analysis and experiments, a representative driving cycle MPKPL was drawn up, making it possible to carry out energy balance for the tested group of vehicles.

The results of measurements and calculations enabled determining: total path, total time, mean speed of driving time, driving time, established motion time, slowing down time as well as elements of energy consumption balance between particular stops on the route.

For the comparative ride of the bus/trolleybus on the route Mickiewicza street - Honorowych Krwiodawców roundabout - Mickiewicza street:

- during the ride on the flat surface the bus is characterized by smaller cycle speedup averages than the trolleybus;

- mileage energy consumption for the bus $\Psi=$ $6 \mathrm{~kJ}$ during the ride on the flat surface is bigger than for the trolleybus $\Psi=2.6 \mathrm{~kJ}$;

- mileage energy consumption for the trolleybus during an uphill ride $\Psi=4 \mathrm{~kJ}$ is bigger than for the bus $\Psi=2.9 \mathrm{~kJ}$.

Obtaining the highest value of total energy consumption for stop No 6 is confirmed on the basis of the registered speed in time function for the trolleybus and the bus; it is connected with the inclination of Piłsudski street in Lublin.

\section{Acknowledgements}

Research conducted as part of the project "Scholarship for postgraduate members of research teams", Operational Programme Human Capital. 


\section{REFERENCES}

1. Chłopek Z., Metodyka szacowania zużycia paliwa przez autobusy na liniach komunikacji miejskiej. Technika w lokalnym transporcie zbiorowym, Kielce, 2004.

2. Ciastoń A., Sapań G., Prędkość komunikacyjna pojazdów w miejskim transporcie zbiorowym. Transport miejski i regionalny 10, 2006.

3. Fice M., Zarządzanie rozpływem energii w napędzie hybrydowym. Rozprawa doktorska PŚ, Gliwice 2010.
4. Ostaszewski J., Energochłonność transportu miejskiego. WKiŁ, Warszawa 1984.

5. Šarkan B., Measurement of fuel consumption of a road motor vehicle by outdoor driving testing. Adv. Sci. Technol. Res. J. 7(19), 2013, 70-74.

6. Siłka W., Analiza energetyczna procesu rozpędzania samochodu. Zeszyty Naukowe WSI, Opole 1993.

7. Siłka W., Analiza wpływu parametrów cyklu jezdnego na energochłonność ruchu samochodu. Zeszyt 14 Monografia 2 PAN oddział Kraków 1998.

8. Wołyńczuk P. Energochłonność, porównanie autobusu i trolejbusu. Praca dyplomowa PL, Lublin 2011.

KAPITAL LUDZKI

NARODOWA STRATECIA SPOUNOBCI 